\title{
Propapoptotic effects of NF- $k$ B in LNCaP prostate cancer cells lead to serine protease activation
}

\author{
K Kimura ${ }^{1}$ and EP Gelmann ${ }^{*, 1}$ \\ 1 Department of Oncology, Lombardi Cancer Center, Georgetown University, \\ 3800 Reservoir Rd, NW Washington, DC 20007-2197, USA \\ * Corresponding author: EP Gelmann, Department of Oncology, Lombardi \\ Cancer Center, Georgetown University, 3800 Reservoir Rd, NW Washington, \\ DC 20007-2197, USA, Tel: 202687 2207; Fax: 202784 1229; \\ E-mail: Gelmanne@georgetown.edu
}

Received 29.6.01; revised 29.1.02; accepted 5.3.02 Edited by CJ Thiele

\section{Abstract}

LNCaP prostate cancer cells are resistant to induction of apoptosis by $\gamma$-irradiation and partially sensitive to TNF- $\alpha$ or FAS antibody, irradiation sensitizes cells to apoptosis induced by FAS antibody or TNF- $\alpha$. LNCaP cell clones stably expressing $\mathrm{I}_{\kappa} \mathrm{B} \alpha$ super repressor were resistant to apoptosis induced by death ligands in the presence or absence of irradiation. $\mathrm{I} \kappa \mathrm{B} \alpha$ super repressor expression also increased clonogenic survival after exposure to TNF- $\alpha$-irradiation, but had no effect on survival after irradiation alone. I $k B \alpha$ super repressor expression blocked the increase of whole cell and cell surface FAS expression induced by TNF- $\alpha$, but did not effect induction of FAS expression and cell surface FAS expression that resulted from irradiation. In cells expressing $\mathrm{I}_{\kappa} \mathrm{B} \alpha$ super repressor there was diminished activation of caspases- 8 and -7 and diminished production of proscaspases-8 and -7 , usually required for death induction in LNCaP cells. Peptide inhibitors of caspase activation complemented the $I_{\kappa} B \alpha$ super repressor inhibition of apoptosis, but peptide inhibitors of serine proteases had no effect on LNCaP cells expressing $I_{k} B \alpha$ super repressor. Moreover, cleavage of a serine protease substrate was induced by treatment of $\mathrm{LNCaP}$ cells with TNF- $\alpha$ and irradiation. The data suggest that in LNCaP cells NF- $\kappa$ B mediates a proapoptotic pathway that leads to activation of proapoptotic serine proteases.

Cell Death and Differentiation (2002) 9 972-980. doi:10.1038/ sj.cdd. 4401049

Keywords: TNF- $\alpha$; FAS; NF- $\kappa \mathrm{B}$; apoptosis; caspase; serine protease

Abbreviations: NF- $\kappa \mathrm{B}$, nuclear factor $\kappa \mathrm{B} ;\left.\right|_{\kappa} \mathrm{B} \alpha$, inhibitor of nuclear factor $\kappa \alpha ; I_{k} \mathrm{BSR}, I_{\kappa} \mathrm{B} \alpha$ super repressor; TNF- $\alpha$, tumor necrosis factor $\alpha$; TNFR1, tumor necrosis factor receptor $1 ; z-V A D, z$-Val-AlaAsp $(\mathrm{OMe})-\mathrm{CH}_{2} \mathrm{~F}$; TLCK, Na-p-tosyl-L-lysine-chloromethylketone; AAD, z-Ala-Ala-Asp(OMe)-CH2F; AAPD-pNa, N-succinyl-Ala-AlaPro-Asp-p-nitroanilide; DEVD, z-Asp-Glu-Val-Asp(OMe)-CH2F, IETD-z-lle-Glu-Thr-Asp(OMe)-CH2F; TRADD, TNF receptor-associated death domain, FAS-associated death domain; FADD, DN, dominant negative mutant of FADD; CARD, caspase activation and recruitment domain; DED, death effector domain; DISC, deathinducing signaling complex

\section{Introduction}

Exposure of certain types of cancer cells to irradiation or cytotoxic chemotherapy induces programmed cell death. ${ }^{1,2}$ Resistance to radiation or chemotherapy can be mediated by interference with apoptotic pathways, suggesting the importance of this mechanism in resistance to cancer treatment. ${ }^{3,4}$ One model system for resistance to radiation-induced apoptosis is the LNCaP prostate cancer cell line, which is hormone-dependent and expresses prostate-specific antigen. We have shown that $\mathrm{LNCaP}$ cells are highly resistant to radiation-induced apoptosis. ${ }^{5}$ Moreover, LNCaP cells undergo growth arrest, but not apoptosis, in response to androgen deprivation, suggesting that these cells may be a model for hormone-independent, radioresistant prostate cancer. LNCaP cells can be induced to undergo apoptosis by combined treatment with irradiation and death ligands. ${ }^{5,6}$

A primary mediator of TNF- $\alpha$ signaling is TNFR1, which forms a trimer in response to ligand binding to initiate the recruitment of a series of adapter molecules to the cytoplasmic portion of the receptor. ${ }^{7}$ The adapter TRADD is recruited to bind to the death domain of TNFR1. ${ }^{8}$ TRADD recruitment initiates the formation of a DISC that can recruit other molecules that initiate at least three other pathways. $^{8,9}$ FADD can complex with TRADD to activate caspase-8 cleavage and other FADD-dependent death pathways. ${ }^{10-12}$ TRADD can recruit RIP, a signaling kinase that interacts with the CARD-containing protein RAIDD. The interaction between RIP and RAIDD activates caspase$2 .^{13-16}$ By recruiting RIP to the DISC, TRADD, through TRAF2, can signal activation of a pathway that results in phosphorylation of $\mathrm{I} \kappa \mathrm{B}$ and activation of $\mathrm{NF}-\kappa \mathrm{B}, \quad \mathrm{a}$ pluripotent transcription factor. ${ }^{9,17-20}$

$\mathrm{NF}-\kappa \mathrm{B}$ is thought to exert an antiapoptotic effect in most cells. NF- $\kappa \mathrm{B}$ modulates the proapoptotic effects of TNF- $\alpha$ and facilitates, in part, the proinflammatory and proliferative effects of this cytokine. ${ }^{17,20-23}$ On the other hand, there are several examples where NF- $\kappa \mathrm{B}$ activation is proapoptotic (reviewed $\mathrm{in}^{23}$ ). In particular, NF- $\kappa$ B activation was important for alphavirus-induced death in AT-3 prostate cancer cells. $^{24,25}$ Although NF- $\kappa$ B may be critical for resistance to chemotherapy-induced death in some cell types, the variable role of $\mathrm{NF}-\kappa \mathrm{B}$ in cell death makes it important to understand fully how NF- $\kappa$ B may mediate cell death. ${ }^{26}$

This paper describes the activation and proapoptotic effects of NF- $\kappa \mathrm{B}$ in LNCaP prostate cancer cells exposed to TNF- $\alpha$ and irradiation. We demonstrate that NF- $\kappa \mathrm{B}$ mediates TNF- $\alpha$-induced increases in FAS expression on the cell surface. NF- $\kappa \mathrm{B}$ also mediates increased levels of 
procaspases that result from death stimuli and are essential for the complete execution of cell death in these malignant epithelial cells.

\section{Results}

\section{The effect of I $\kappa$ BSR on LNCaP cell death}

To determine the role of $\mathrm{NF}-\kappa \mathrm{B}$ in apoptosis induced by TNF- $\alpha$ and irradiation, we derived stable clones of LNCaP cells transfected with $\mid \kappa B S R$. I $\kappa$ BSR contains serine to alanine mutations at amino acids 32 and 36 to prevent the phosphorylation that targets $I_{\kappa} \mathrm{B}$ for proteasomal degradation. Expression of $\mathrm{I} \kappa \mathrm{BSR}$ was demonstrated by Western blotting and the effect on NF- $\kappa \mathrm{B}$ transcriptional activity was shown by reporter gene assay (Figure 1 ). I $\kappa$ BSR expression blocked NF- $\kappa$ B activation by TNF- $\alpha$ almost completely (Figure 1B). Blockade of TNF- $\alpha$ signaling by expression of FADD-DN did not interfere with NF- $\kappa$ B activation in LNCaP cells $^{6}$ (Figure 1B). We have previously shown that the synthetic androgen R1881, which is a potent inhibitor of apoptosis, has no effect on NF- $\kappa$ B activity in LNCaP cells. ${ }^{27}$ Therefore, variation in NF- $\kappa \mathrm{B}$ activity does not necessarily

A.

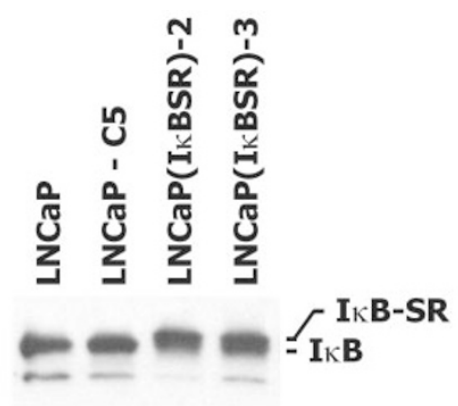

B.

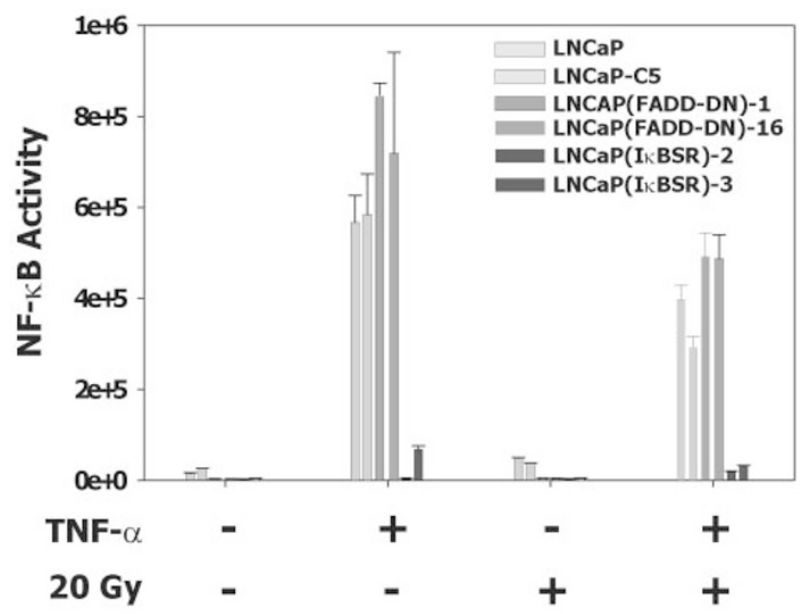

Figure 1 Expression of $\left.\right|_{\kappa}$ BSR in LNCaP cells. (A) $\left.\right|_{\kappa} B$ and $\left.\right|_{\kappa}$ BSR Proteins were detected by the western blotting with an antibody to $\left.\right|_{\kappa} \mathrm{B} \alpha$. The lower band indicates wild-type $I_{\kappa} \mathrm{B}$. The upper band represents $\mathrm{I}_{\kappa} \mathrm{BSR}$. (B) NF- $\kappa \mathrm{B}$ activity induced by $40 \mathrm{ng} / \mathrm{ml} \mathrm{TNF}-\alpha$ and/or 20 Gy irradiation in $\mathrm{K}_{\kappa} \mathrm{BSR}$ transformants. The activity was examined at $6 \mathrm{~h}$ after the treatment by the luciferase assay using the NF- $\kappa \mathrm{B}$ transcription reporter vector accompany interference with LNCaP cell death induction or exposure to irradiation.

Expression of $\mathrm{I} \kappa \mathrm{BSR}$ diminished $\mathrm{LNCaP}$ cell apoptosis at the 72-h time point after exposure to TNF- $\alpha$ (Figure 2, bottom panel). ${ }^{5}$ Treatment of LNCaP cells with the agonistic FAS antibody $\mathrm{CH}-11$ has an even smaller death effect on LNCaP cells than TNF- $\alpha$ and was inhibited to a small degree up to $72 \mathrm{~h}$ after exposure by $\mathrm{I} \kappa \mathrm{BSR}$ expression (Figure 2, bottom panel). ${ }^{6}$ Activation of FAS is not thought to activate NF- $\kappa \mathrm{B}$ activity. Irradiation, however, enhances death induction by $\mathrm{CH}-11$ or TNF- $\alpha .{ }^{5,6}$ Apoptosis
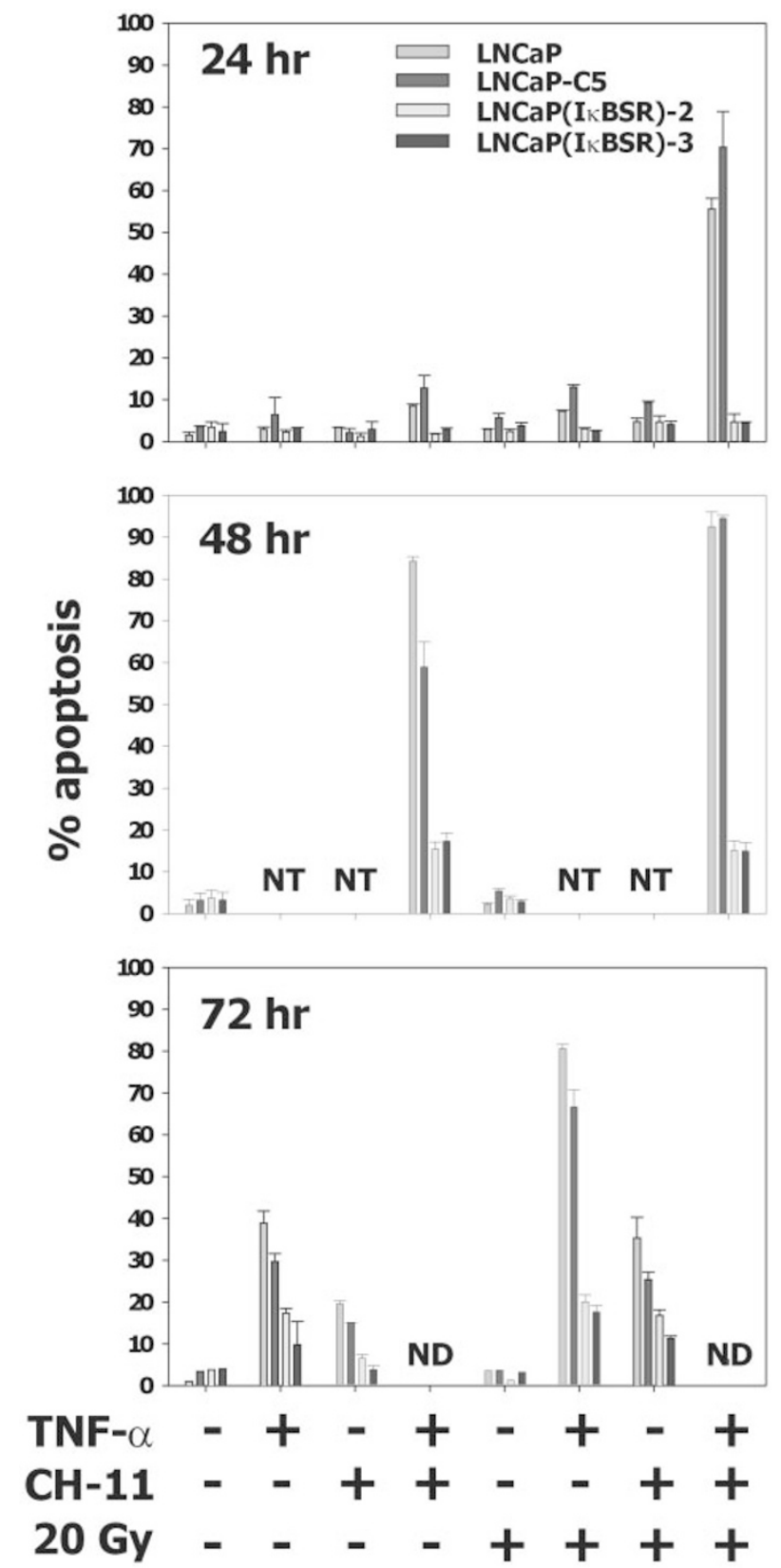

Figure 2 Effect of $\mathrm{I}_{\kappa} \mathrm{BSR}$ on LNCaP cell death. Apoptosis was assayed 24 , 48 , and $72 \mathrm{~h}$ after treatment with $40 \mathrm{ng} / \mathrm{ml} \mathrm{TNF}-\alpha, 0.5 \mu \mathrm{g} / \mathrm{ml} \mathrm{CH}-11$, and $/ 0 \mathrm{r} 20$ Gy irradiation 
induced by TNF- $\alpha+$ irradiation was inhibited by $\mathrm{I}_{\kappa} \mathrm{BSR}$ expression (Figure 2). Apoptosis induced by $\mathrm{CH}-11+$ irradiation was inhibited transiently and to a small degree by I $\kappa$ BSR expression (Figure 2). This is consistent with our observations that $\mathrm{CH}-11$ treatment of $\mathrm{LNCaP}$ cells has minimal effects on NF- $\kappa$ B activity (not shown).

Simultaneous exposure of LNCaP cells to both $\mathrm{CH}-11$ and TNF- $\alpha$ induces cell death within $24 \mathrm{~h}$ of exposure by a synergistic activation of caspases. ${ }^{6}$ Under these conditions I $\kappa$ BSR expression effectively protected LNCaP cells from apoptosis (Figure 2, top and center panels). The addition of irradiation to $\mathrm{CH}-11$ and TNF- $\alpha$ accelerates the effect of combined treatment of the two death ligands. ${ }^{6}$ Cell death induced by combined death ligand and irradiation was also blocked by $\mathrm{I}_{\kappa} \mathrm{BSR}$ expression. (Figure 2, top and center panels).

We also examined the effect of $\mathrm{I}_{\kappa} \mathrm{BSR}$ expression on clonogenic survival of LNCaP cells after irradiation. After exposure to irradiation alone, there was possibly a small effect on clonogenicity seen in $\mathrm{LNCaP}\left(\mathrm{I}_{\kappa} \mathrm{BSR}\right)$ clones compared to control clones (10\% survival fraction at 600 vs 400 cGy, Figure $3 \mathrm{~A}$ ). Note that the survival curves of the two $I_{\kappa}$ BSR expressing clones lie to the right of the parental
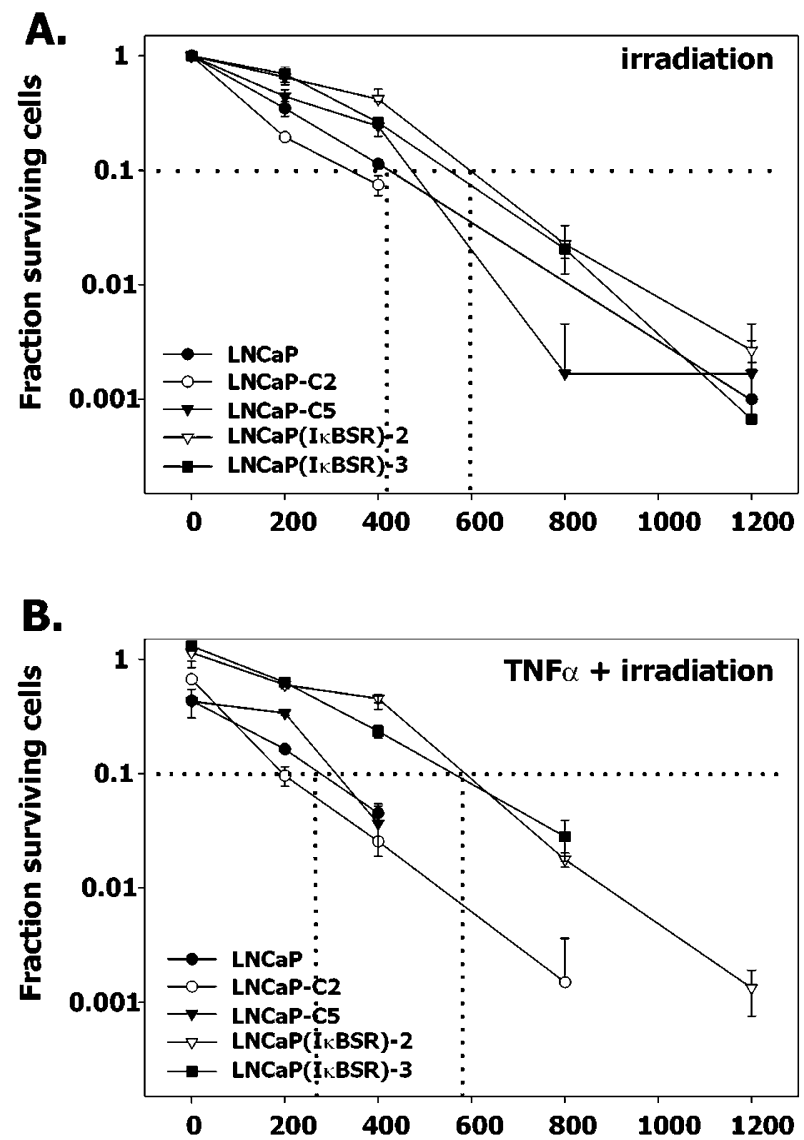

Figure 3 Clonogenic survival of $\mathrm{LNCaP}$ cells and derivative lines after exposure to irradiation or to TNF- $\alpha+$ irradiation. Colony-forming efficiency was measured 10 days after exposure to different doses of irradiation and $40 \mathrm{ng} / \mathrm{ml}$ TNF- $\alpha$. Fraction surviving cells was determined as described in Materials and Methods and control LNCaP cells. I $\kappa$ BSR expression was completely protective against the additional effects that TNF- $\alpha$ conferred on clonogenicity after irradiation-induced cell killing. In the presence of TNF- $\alpha 10 \%$ survival fraction was seen at 275 cGy for control cells and was at 600 cGy, similar to irradiation alone, in $\mathrm{I}_{\kappa} \mathrm{BSR}$ expressing cells (Figure $3 \mathrm{~B}$ ). Although the slopes of the survival curves were not affected by $I_{\kappa} \mathrm{BSR}$ expression, a higher fraction of cells survived irradiation at each dose.

\section{Effect of $\mathrm{I}_{\kappa} \mathrm{BSR}$ on induction of FAS expression}

Exposure of LNCaP cells to TNF- $\alpha$ does not affect expression of TNFR1, but does increase TNF- $\alpha$ and FAS expression. ${ }^{6}$ FAS expression increases within hours of TNF- $\alpha$ exposure whereas apoptosis cannot be detected until two days after TNF- $\alpha$ exposure. ${ }^{6}$ We examined the role of NF- $\kappa \mathrm{B}$ in the modulation of FAS expression by TNF- $\alpha$. At $24 \mathrm{~h}$ after TNF- $\alpha$ exposure FAS expression increased in LNCaP cells (Figure 4A top panel). Activation of FAS expression by TNF- $\alpha$ was abrogated by $\mid \kappa B S R$ expression (Figure $4 \mathrm{~A}$ ). We also observed a radiation-induced increase in FAS expression that was independent of NF- $\kappa \mathrm{B}$. The absolute FAS expression levels cannot be compared between the panels in Figure 4A because of differences in exposure times of the Western blots.
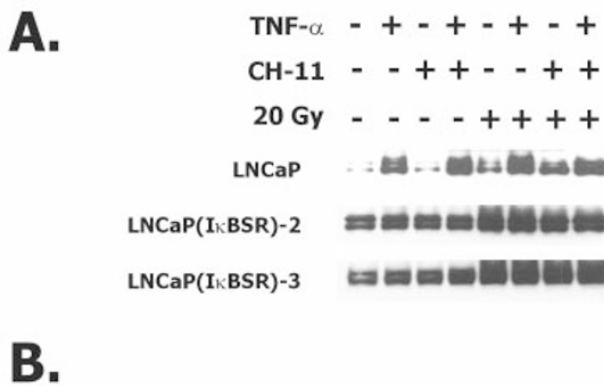

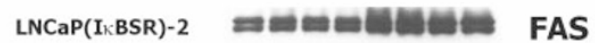

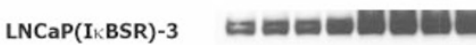

B.

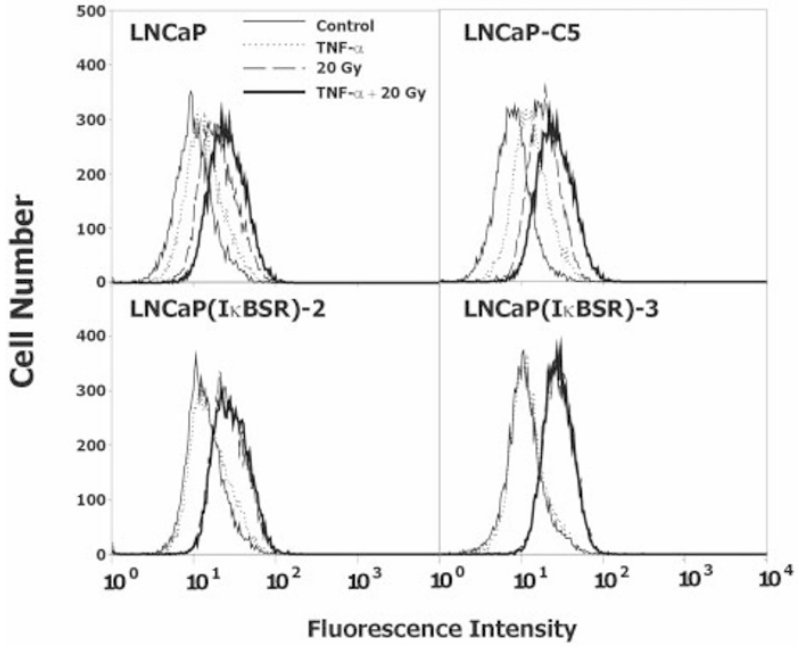

Figure 4 The effect of $I_{\kappa} B S R$ on FAS expression. (A) Western blotting for expression of FAS in whole cell protein extracts $24 \mathrm{~h}$ after the treatment with $40 \mathrm{ng} / \mathrm{ml} \mathrm{TNF}-\alpha, 0.5 \mu \mathrm{g} / \mathrm{ml} \mathrm{CH}-11$, and/or $20 \mathrm{~Gy}$ irradiation. (B) FACS analysis for expression of cell surface FAS $24 \mathrm{~h}$ after exposures as indicated 
In addition to observing changes in FAS expression, we also observed alterations in the amounts of cell surface FAS by TNF- $\alpha$ and irradiation. TNF- $\alpha$ increased cell surface FAS levels; irradiation had a greater effect on cell surface FAS; combined TNF- $\alpha$ and irradiation had an additive effect causing the greatest increase in observed cell surface FAS (Figure 4B top). The effect of TNF- $\alpha$ on cell surface FAS expression, but not the effect of irradiation, was abrogated by $\mathrm{I}_{\kappa} \mathrm{BSR}$. However, there was no effect of $\mid \kappa \mathrm{BSR}$ on increases in cell surface FAS expression induced by irradiation (Figure 4B bottom).

\section{I $\kappa$ BSR effect on caspases}

Induction of cell death in prostate cancer cell lines requires both caspase activation and sustained synthesis of procaspases. $^{6,28}$ Activation of caspase-8, a proximal signaling caspase, by TNF- $\alpha+$ irradiation, $\mathrm{CH}-11$ +irradiation or TNF$\alpha+\mathrm{CH}-11+$ irradiation was not blocked by expression of $\mathrm{I}_{\kappa} \mathrm{BSR}$ even though apoptosis was blocked (Figure 5). The primary effector of cell death in LNCaP cell is caspase-7.6,29 Activation of caspase-7 was not seen in $1 \kappa$ BSR expressing cells. However, increases in both procaspase- 8 and procaspase-7 expression by TNF- $\alpha$ seen in LNCaP cells was abrogated by $I_{\kappa} \mathrm{BSR}$ expression. The increase of procaspase expression induced by $\mathrm{TNF}-\alpha+\mathrm{CH}-11$ treatment was also blocked by $\mathrm{I}_{\kappa} \mathrm{BSR}$ (Figure 5 ).

$\mathrm{TNF}-\alpha$ and irradiation induce $\mathrm{LNCaP}$ cell death that is mediated by both cysteine and serine proteases. ${ }^{5}{ }_{1} \mathrm{BSR}$

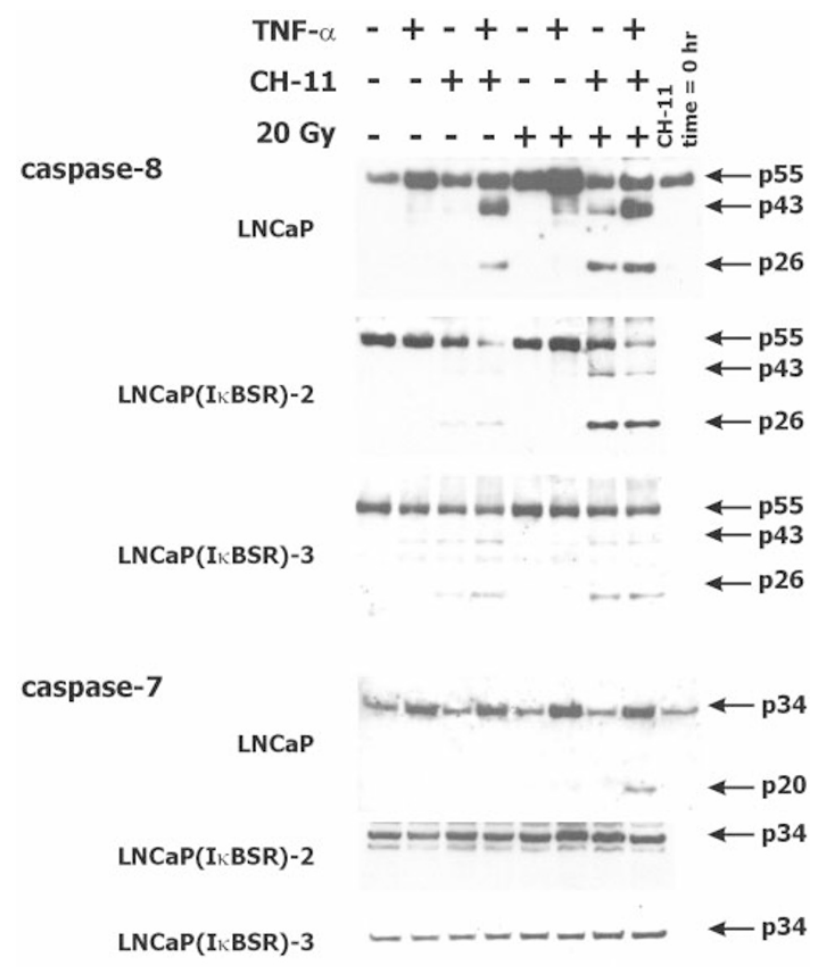

Figure 5 The effect of $I_{\kappa} \mathrm{BSR}$ on caspase cleavage. Western blotting for caspase- 8 and caspase- 7 on cell extracts obtained $24 \mathrm{~h}$ after treatment with $40 \mathrm{ng} / \mathrm{ml} \mathrm{TNF}-\alpha, 0.5 \mu \mathrm{g} / \mathrm{ml} \mathrm{CH}-11$, and/or 20 Gy irradiation expression did not completely block apoptosis and caspase activation. To determine the role of the residual caspase activity in $\mathrm{LNCaP}\left(\mathrm{I}_{\kappa} \mathrm{BSR}\right)$ cell death we used peptide inhibitors of death proteases (Figure 6). The pancaspase inhibitor zVAD, the caspase-8 inhibitor IETD, and the inhibitor of caspases-8 and -7 DEVD, all blocked residual apoptosis induced by TNF- $\alpha$ and irradiation in LNCa$\mathrm{P}\left(\mathrm{I}_{\kappa} \mathrm{BSR}\right)$ cells. The inhibitors only partially blocked apoptosis in the control cells because serine protease activity also contributes to cell death. ${ }^{5}$ TLCK, a serine protease inhibitor, partially blocked apoptosis induced by TNF- $\alpha$ and irradiation in control cells, but had no effect on cell death in LNCaP cells expressing I $\kappa$ BSR. The data imply that $\mid \kappa B S R$ expression fully inhibited serine protease activation in LNCaP cells. In contrast to the effect of TLCK on cell death induced by TNF- $\alpha \pm$ irradiation, TLCK had no effect on cell death induced by $\mathrm{CH}-11 \pm$ irradiation, even at $90 \mathrm{~h}$ after treatment of the cells (Figure 7). Moreover, by $90 \mathrm{~h}$ after exposure to $\mathrm{CH}-11 \pm$ irradiation there was no discernable effect of $\mathrm{I}_{\kappa} \mathrm{BSR}$ expression on cell death induced by $\mathrm{CH}-11+$ irradiation. This is in contrast to the small inhibitory effect seen up to $72 \mathrm{~h}$ after exposure (Figure 2).

TLCK may have interfered with cell death by inhibition of trypsin-like proteases ${ }^{30-32}$ or by inhibition of $\mathrm{NF}-\kappa \mathrm{B}$ synthesis. $^{33-35}$ In fact, although $\mathrm{ZVAD}$ had no effect on $\mathrm{NF}-\kappa \mathrm{B}$ activity, TLCK did reduce NF- $\kappa \mathrm{B}$ activity in LNCaP cells presumably by inhibition of $\mathrm{I} \kappa \mathrm{B}$ degradation (Figure $8 \mathrm{~A})$. Since the proapoptotic effect of $\mathrm{NF}-\kappa \mathrm{B}$ was mediated by several mechanisms, we wanted to be sure that we could selectively inhibit serine protease activity without affecting NF- $\kappa \mathrm{B}$ activity. We examined the effect of the granzyme $B$ inhibitor, AAD, on apoptosis induced by TNF$\alpha$ +irradiation. ${ }^{36}$ Unlike TLCK, AAD had only minimal effects on induction of NF- $\kappa$ B activity by TNF- $\alpha$ (Figure $8 B$ ). AAD partially inhibited apoptosis induced by $T N F-\alpha$ plus irradiation, but not by TNF- $\alpha$ alone (Figure $8 \mathrm{C}$ ). We previously showed that TLCK and ZVAD or DEVD each partially inhibited LNCaP cell death after TNF- $\alpha+$ irradiation, but TLCK+ZVAD together completely inhibited apoptosis. ${ }^{5}$ Similarly, AAD partially inhibited LNCaP cell apoptosis after TNF- $\alpha+$ irradiation as did IETD. However, together, AAD and IETD inhibited cell death nearly completely, even at $72 \mathrm{~h}$ after exposure. Consistent with the notion that TLCK and $A A D$ block the same death proteases, treating $\mathrm{LNCaP}$ cells with both AAD and TLCK had only a minimally greater effect than either compound alone.

We were able to demonstrate the activation of serine protease activity using the fluorescent substrate AAPDpNa. At $24 \mathrm{~h}$ after treatment with TNF- $\alpha+$ irradiation we observed a $90 \%$ increase of AAPD-pNa activity over baseline. We observed some increase of AAPD-pNa activity in radiation-treated cells as well, although the data was not statistically significant (Figure 8D). We found that AAPD-pNa activity was attenuated in $1 \kappa$ BSR-expressing cells (data not shown). When we treated LNCaP cells expressing $I_{\kappa} B S R$ with $A A D$, we observed no incremental inhibition of cell death compared to control similar to the effect of TLCK (Figure 8E). AAD did inhibit cell death of parental LNCaP cells and control transfectants. 
A.

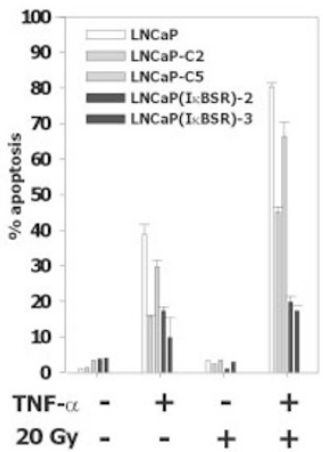

B.

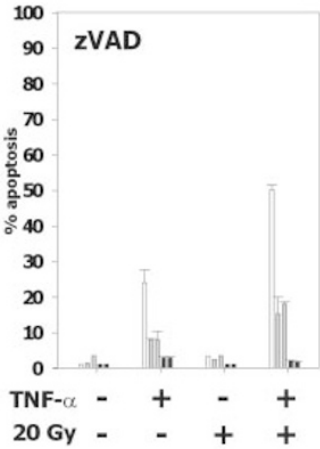

C.

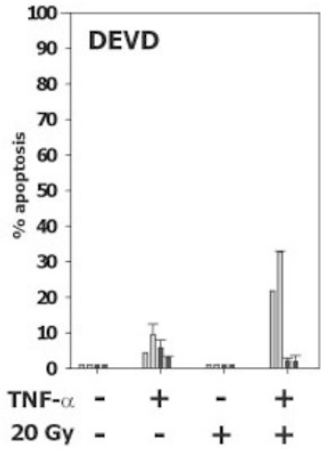

D.

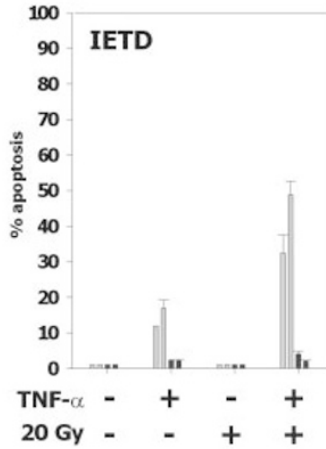

E.

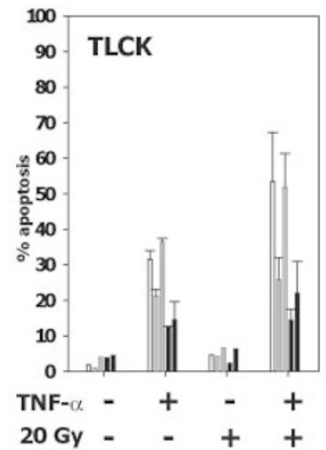

Figure 6 The effect of caspase inhibitors and TLCK on the apoptosis induced by $40 \mathrm{ng} / \mathrm{ml} \mathrm{TNF-} \alpha$ and/or 20 Gy irradiation. Apoptosis was assayed $72 \mathrm{~h}$ after treatment of $\mathrm{LNCaP}$ cells, control transfected clones $\mathrm{C} 2$ and $\mathrm{C} 5$, and $\mathrm{I}_{\kappa} \mathrm{BSR}$ transfectants

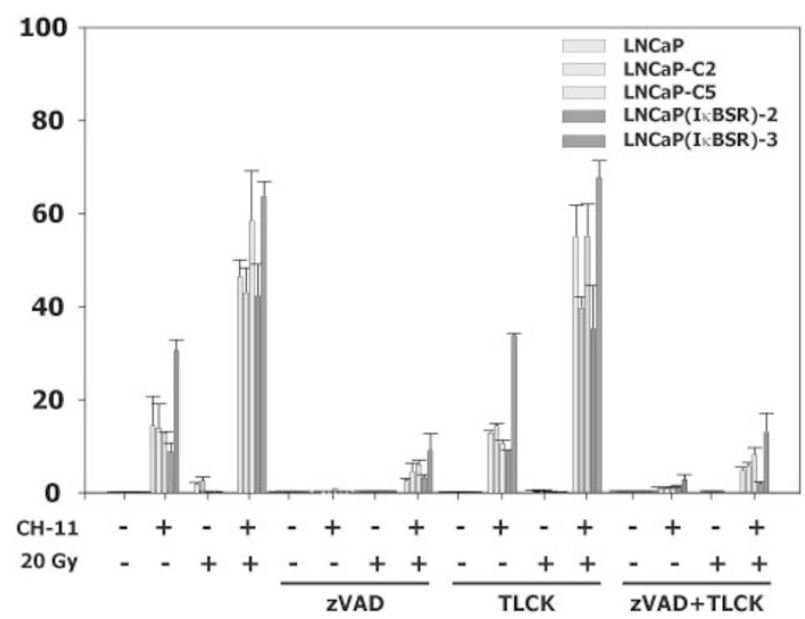

Figure 7 Effect of protease inhibitors on cell death induction by $\mathrm{CH}$ $11 \pm$ irradiation. Cell death was measured at $90 \mathrm{~h}$ after exposure to allow for sufficient cell death in cultures treated with $\mathrm{CH}-11$ alone. Peptide inhibitors were used as described in Figure 6 and in Materials and Methods

\section{Discussion}

TNF- $\alpha$ activation of NF- $\kappa$ B has an antiapoptotic effect in many cell lines. The relative level of NF- $\kappa \mathrm{B}$ activation may help determine whether TNF- $\alpha$ induces proliferation or apoptosis of a target cell. ${ }^{17,26,37,38}$ However, NF- $\kappa \mathrm{B}$ can also mediate cell death. ${ }^{39-43}$ In particular, NF- $\kappa$ B may be important for P53mediated cell death. LNCaP cells are known to have a normal P53 complement. Irradiation, although not active alone to activate biochemical pathways of apoptosis of $\mathrm{LNCaP}$ cells, could potentially have activated P53 and thereby sensitized the cells to initiation of a cell death cascade. Irradiation of LNCaP cells does result in induction of P53 expression (our unpublished data). Our data are consistent with this interpretation since we have shown that expression of $I_{\kappa} \mathrm{BSR}$ modulates the degree of cell death after TNF- $\alpha$ +irradiation compared to that seen with TNF- $\alpha$ alone. Based on the results of our clonogenicity experiment (Figure 3) irradiation of LNCaP cells can decrease cell viability without activating apoptosis.
NF- $\kappa \mathrm{B}$ appeared to affect many events during cell death. In particular, increases in FAS levels and subcellular localization of FAS were altered in the presence of $I_{\kappa} \mathrm{BSR}$. $N F-\kappa B$ has previously been shown to mediate activation of FAS expression in adenovirus-induced hepatocyte death. ${ }^{44}$ We also observed that induction of procaspase expression which is required for the execution of prostate cancer cell death, was abrogated by $1 \kappa \mathrm{BSR}$ expression. ${ }^{28}$ We have shown that increased procaspase expression results from posttranscriptional activation. Therefore, the effect of NF- $\kappa B$ on procaspase expression is not via transcriptional activation of procaspase genes.

Our data imply that inhibition of NF- $\kappa \mathrm{B}$ substantially inhibited activation of serine proteases. Our previous papers describing the effect of TNF- $\alpha$ +irradiation on LNCaP cells suggested that there were two protease pathways resulting in cell death, one mediated by caspase activation and one by serine protease activation. ${ }^{5,6}$ Although caspases are specific agents of cell death, all cell death is not mediated by caspases. In numerous cell systems serine proteases have been shown to be important mediators of apoptosis. ${ }^{45-49}$ In some cells characteristic morphologic changes of apoptosis occur entirely in the absence of caspase activation. ${ }^{32}$ The identification of specific serine proteases involved in apoptosis is not as advanced as identification of caspases. Investigators have relied on cell permeable inhibitors of serine proteases to define their presence in cell death cascades. ${ }^{48}$ We have found that the serine protease inhibitor TLCK is effective at blocking LNCaP cell death to an equal degree as caspase inhibitors. ${ }^{30,50}$ Serine proteases that have been implicated in cell death include cathepsin D. ${ }^{51}$ We found no evidence of cathepsin D activation during apoptosis of $\mathrm{LNCaP}$ cells after exposure to TNF- $\alpha$ and irradiation (our unpublished observations). In general, serine protease activation in cell death has been described in nonlymphoid cells that require hours to days to execute apoptosis after a death stimulus. ${ }^{5,47,52}$ Serine protease activation is independent of caspase activation and there was no effect of ZVAD on TLCK-sensitive cell death. ${ }^{5}$ However, serine protease activation depended on FADD, which in our system controlled all cell death signals initiated by TNF- $\alpha+$ irradiation. Although NF- $\kappa$ B activation is 
A.

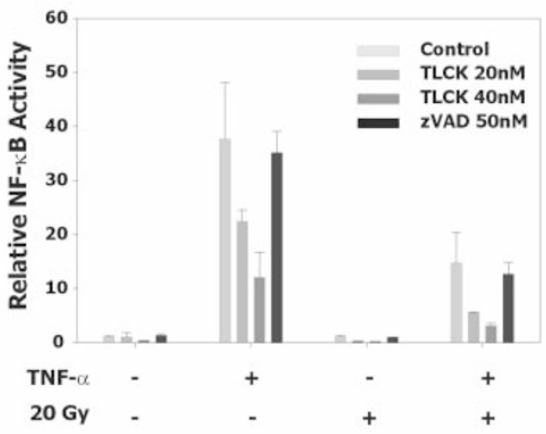

C.
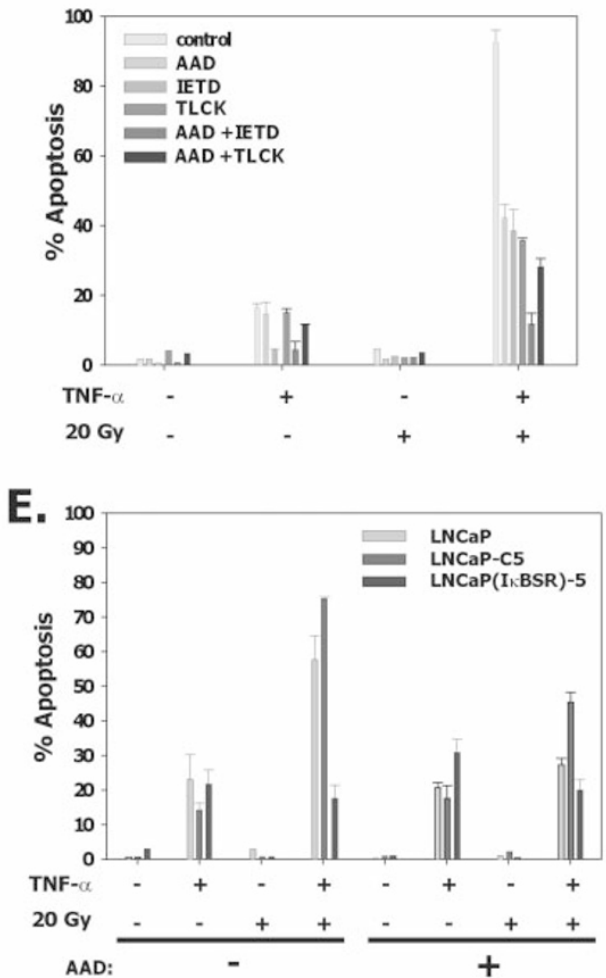

B.

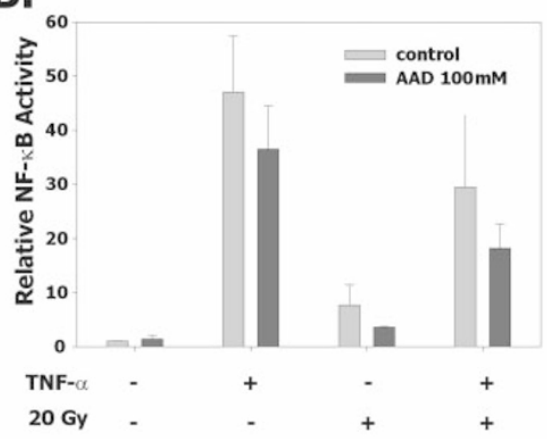

D.

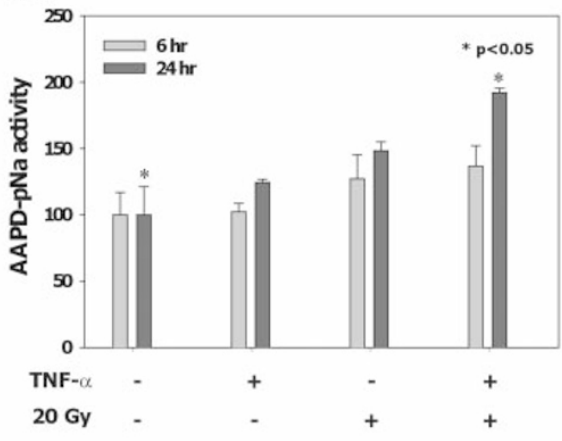

Figure 8 Effects of serine protease inhibitors. (A) The effect of TLCK and zVAD on NF- $\kappa$ B activity induced in LNCaP cells by 40 ng/ml TNF- $\alpha$ and/or 20 Gy irradiation. (B) The effect of AAD on NF- $\kappa$ B activity induced in LNCaP cells by $40 \mathrm{ng} / \mathrm{ml}$ TNF- $\alpha$ and/or 20 Gy irradiation. In panels $(\mathbf{A})$ and $(\mathbf{B})$ NF- $\kappa$ B activity was assayed $6 \mathrm{~h}$ after treatment using a luciferase reporter assay. (C) The effect of $100 \mu \mathrm{M} \mathrm{AAD}, 50 \mu \mathrm{M}$ IETD, and $40 \mu \mathrm{M}$ TLCK on LNCaP cell apoptosis induced by TNF- $\alpha$ and/or irradiation at $72 \mathrm{~h}$ after treatment in. (D) The effect of TNF- $\alpha$ and/or irradiation on AAPD-pNa cleavage activity in cell extracts at the indicated times after treatment with TNF- $\alpha$ and/or 20 Gy irradiation. (E) The effect of $100 \mu \mathrm{M} \mathrm{AAD}$ on apoptosis induced by TNF- $\alpha$ and/or irradiation in I $\kappa$ BSR transformants

not dependent on FADD, ${ }^{17}$ caspase-8 activation has been shown to activate NF- $\kappa \mathrm{B}$. Moreover, because of the antiapoptotic effect of FADD-DN, we infer that FADD must either influence serine protease activation at some point downstream from NF- $\kappa$ B activation or via caspase-8. ${ }^{37}$

Although $\gamma$-irradiation is a potent sensitizer for LNCaP cell apoptosis, we have never observed caspase activation or LNCaP cell death in response to irradiation alone. ${ }^{5,6}$ Whereas there have been reports that the insensitivity of LNCaP cells to death induction by TPA is related to deficiency in ceramide synthase, we have not observed effects of a ceramide synthase inhibitor, fumonisin B1 on cell death induced by TNF- $\alpha+$ irradiation. ${ }^{53,54}$ Some reports would suggest that an increase in NF- $\kappa$ B activity would have been seen after irradiation. ${ }^{55}$ However, we also saw no chronic increase of NF- $\kappa \mathrm{B}$ activity after irradiation. Even within minutes or up to $6 \mathrm{~h}$ after irradiation with 20 Gy we have not observed NF- $\kappa$ B activation (our unpublished data). Nevertheless, irradiation must cause changes in LNCaP cells that predispose to augmentation of the cell death response and serine protease activation when cells are exposed to TNF- $\kappa$ at the time of irradiation. Compared to TNF- $\alpha$ alone, TNF- $\alpha+$ irradiation caused more extensive cell death, a higher degree of caspase activation, more 
ceramide generation, increased caspase- 9 cleavage, and serine protease activation. All these effects are FADDdependent and protease mediated. ${ }^{5,6}$

There are several reports showing that activation of NF$\kappa \mathrm{B}$ can be blocked by serine protease inhibitors such as TLCK or TPCK through the inhibition of $I \kappa B$ degradation. We found that $\mathrm{NF}-\kappa \mathrm{B}$ activation by $\mathrm{TNF}-\alpha$ plus radiation was partially blocked by TLCK. Therefore, its effect on NF$\kappa \mathrm{B}$ may have confused the interpretation that TLCK inhibited downstream serine proteases involved in cell death. Since zVAD did not achieve total blockade of LNCaP cell death after exposure to TNF- $\alpha+$ irradiation, we had good reason to believe that serine proteases were involved in execution of cell death. By using $A A D$, a peptide inhibitor designed to block the serine protease granzyme $B$, and its fluorigenic substrate, we confirmed that noncaspase proteases were indeed active during induction of $\mathrm{LNCaP}$ cell death. $A A D$ had been shown to inhibit radiationmediated apoptosis in MOLT-4 lymphoblastic leukemic cells. ${ }^{47}$ We were able to show that two different serineprotease inhibitors blocked the apoptosis induced by TNF$\alpha+$ irradiation, including one that had minimal effect on NF$\kappa \mathrm{B}$ transcriptional activity, thereby supporting our conclusion that in LNCaP cells NF- $\kappa$ B mediated cell death in part by serine protease activation.

\section{Materials and Methods}

\section{Cell culture}

Human prostate cancer cells were grown and treated with death ligands as previously described. ${ }^{6}$ Caspase inhibitors, zVAD, DEVD, IETD were purchased from Enzyme Systems Products (Livermore, CA, USA). Serine protease inhibitor, TLCK was purchased from Sigma (St. Louis, MO, USA). The granzyme B inhibitor z-Ala-Ala-Asp(OMe)$\mathrm{CH} 2 \mathrm{~F}$ (AAD) was purchased from Enzyme Systems Products (Livermore, CA, USA). Either caspase inhibitors, AAD, or TLCK were added $1 \mathrm{~h}$ before treatment of cells with either TNF- $\alpha, \mathrm{CH}-11$, or $\gamma$ irradiation. For $\gamma$-irradiation we used a JL Shepherd Mark I Irradiator $\left[{ }^{137} \mathrm{Cs}\right]$ source with a dose rate of $209 \mathrm{cGy} / \mathrm{min}$.

\section{Construction of FADD-DN and $\epsilon_{\kappa}$ BSR transformants}

LNCaP cells stably expressing FADD-DN have been previously described. $^{6}$ LNCaP cells expressing $I_{\kappa} \mathrm{BSR}$ were derived by transfection with pCMV 4 containing an $\mid \kappa B \alpha$ with two mutations that changed two amino acids corresponding with phosphorylation sites located at amino acid residues 32 and 36 to serine and alanine respectively, was a gift from Dr. Ulrich Siebenlist (NIH, Bethesda, MD, USA). This $\left.\right|_{k} B S R$ mutant gene was recloned into the expression vector pcDNA3.1(+) and used for making transformants. The vectors were transfected into LNCaP cells using effectene (Qiagen Company, Valencia, CA, USA), and the transformants were selected by G418. The expression of $l_{\kappa} B S R$ was confirmed by the Western blotting using anti-I $\kappa$ B polyclonal antibody (Santa Cruz Biotechnology, Santa Cruz, $\mathrm{CA}, \mathrm{USA})$. Three representative clones $\mathrm{LNCaP}(\mathrm{I} \kappa \mathrm{BSR})-2,-3$, and -5 were selected for the data shown in this report. Control transfected cells, LNCaP-C2 and LNCaP-C5, expressed empty expression vector with the neomycin-resistance gene.

\section{Clonogenicity assays}

The experiments were done as described by Kyprianou et al. ${ }^{56}$ Briefly, parental LNCaP cells and their clones were plated in 6-well dishes. After irradiation with $2-12 \mathrm{~Gy} \pm 40 \mathrm{ng} / \mathrm{ml} \mathrm{TNF}-\alpha$ cells were incubated for $24 \mathrm{~h}$ and then plated at a density of 1000 cells/per well in triplicate sixwell dishes in fresh medium. Colonies of 30 cells or more at 10 days were counted as surviving. Colony-forming efficiency was defined as the ratio of the number of colonies to the number of plated cells. Fraction surviving cells were defined as the ratio of colony-forming efficiency of cells under particular treatment to that of cells without irradiation.

\section{Apoptosis assays}

The in situ end-labeling assay is routinely used in our laboratory for apoptosis determination and has been previously described. ${ }^{5}$

\section{Western blotting}

One hundred $\mu \mathrm{g}$ of total cellular protein was resolved by electrophoresis on $10-20 \%$ acrylamide gels and blotted as previously described. $^{5}$ The membranes were probed with either mouse monoclonal antibody to caspase-8 (Cell Diagnostica, Muenster, Germany), rabbit polyclonal antibody to caspase-7 (Cell Signaling Technology Inc., Beverly, MA, USA), or rabbit polyclonal anti-Fas antibody (Santa Cruz Biotechnology Inc., Santa Cruz, CA, USA), and further incubated with either goat anti-mouse IgG conjugated with horseradish peroxidase or goat anti-rabbit IgG conjugated with horseradish peroxidase (Pierce, Rockford, IL, USA). The bands were visualized with enhanced chemiluminescence detection (Pierce).

\section{Assay for cell surface Fas receptor}

The cells were washed with PBS (-) containing $0.1 \%$ bovine serum albumen twice and incubated with mouse anti-human CD95 antibody conjugated with fluorescein isothiocyanate (FITC) (Pharmingen, San Diego, CA, USA) for $1 \mathrm{~h}$ at $4^{\circ} \mathrm{C}$. The cells were washed again with PBS $(-)$ plus $0.1 \%$ BSA, and then suspended into the culture medium. The samples were analyzed at $488 \mathrm{~nm}$ argon laser by flow cytometry (FACStar plus, Beckton Dickinson, San Diego, CA, USA).

\section{NF- $\kappa$ B transcriptional activity assay}

The NF- $\kappa \mathrm{B}$ transcription reporter vector, pNF- $\kappa \mathrm{B}-$ Reporter, was purchased from Clonetech Laboratories Inc. (Palo Alto, CA, USA). After the vector was transiently transfected into cells with effectene, the cells were cultured in IMEM w/o phenol red with 5\% CCS overnight. The cells were treated with TNF- $\alpha$ and/or irradiation. Six hours after the treatment, the cells were washed and dissolved into the solubilization buffer which was a part of the luciferase assay kit (Promega Corp., Madison, WI, USA). The assay of transcriptional activity by measuring the intensity of luminescence was performed according to the manufacturer's protocol (Promega). The luminescence was measured by the luminometer, Lumat LB9501 (Berthold Pty Ltd., Bundoora, Australia).

\section{AAPD-pNa cleavage assay}

$\mathrm{N}$-succinyl-Ala-Ala-Pro-Asp-p-nitroanilide(AAPD-pNa) was used as a preferred substrate for the serine protease granzyme B (Sigma). The assay was performed based upon the method of Gong et al, ${ }^{47}$ except for the lysis and reaction buffer. We used the lysis and reaction buffer 
for IETD-AFC assay system (Clonetech Laboratories Inc., Palo Alto, CA, USA) instead of the one that was used by Gong et al. ${ }^{47}$ We used $200 \mu \mathrm{g}$ protein per assay instead of $20 \mu \mathrm{g}$ per assay. AAPD-pNa cleavage was monitered by enzyme-catalyzed release of $\mathrm{pNa}$, by determining absorbance at $410 \mathrm{~nm}$ in a DU-65 spectrophotometer (Beckmann Coulter Inc., Fullerton, CA,USA).

\section{Acknowledgements}

We thank Cai Bowen and Mark Markowski for assistance with some of the experiments. We are grateful to Sarah Spiegel for helpful discussions. This work was supported by NIH grant CA 79912 to EP Gelmann.

\section{References}

1. Algan O, Stobbe CC, Helt AM, Hanks GE and Chapman JD (1996) Radiation inactivation of human prostate cancer cells: the role of apoptosis. Radiat. Res. 146: $267-275$

2. Reed CJ (2000) Apoptosis and cancer: strategies for integrating programmed cell death. Semin. Hematol. 37: 9-16

3. Arceci RJ (1996) Tumor cell survival and resistance to therapy. Curr. Opin. Hematol. 3: 279-287

4. Denmeade SR, Lin XS and Isaacs JT (1996) Role of programmed (apoptotic) cell death during the progression and therapy for prostate cancer [published erratum appears in Prostate 1996 Jun; 28(6): 414]. Prostate 28: 251-265

5. Kimura K, Bowen C, Spiegel S and Gelmann EP (1999) Tumor necrosis factoralpha sensitizes prostate cancer cells to gamma-irradiation-induced apoptosis. Cancer Res. 59: 1606-1614

6. Kimura K and Gelmann EP (2000) Tumor Necrosis Factor-alpha and Fas Activate Complementary Fas- associated Death Domain-dependent Pathways That Enhance Apoptosis Induced by gamma-Irradiation. J. Biol. Chem. 275: $8610-8617$

7. Wallach D, VarfolomeevEE, Malinin NL, Goltsev YV, Kovalenko A and Boldin MP (1999) Tumor necrosis factor receptor and Fas signaling mechanisms. Ann. Rev. Immunol. 17: 331-367

8. Hsu H, Xiong J and Goeddel DV (1995) The TNF receptor 1-associated protein TRADD signals cell death and NF- kappa B activation. Cell 81: 495-504

9. Hsu H, Shu HB, Pan MG and Goeddel DV (1996) TRADD-TRAF2 and TRADDFADD interactions define two distinct TNF receptor 1 signal transduction pathways. Cell 84: 299-308

10. Wiegmann K, Schwandner R, Krut O, Yeh WC, Mak TW and Kronke M (1999) Requirement of FADD for tumor necrosis factor-induced activation of acid sphingomyelinase. J. Biol. Chem. 274: 5267-5270

11. Juo P, Woo MS, Kuo CJ, Signorelli P, Biemann HP, Hannun YA and Blenis J (1999) FADD is required for multiple signaling events downstream of the receptor Fas. Cell Growth Differ. 10: 797-804

12. Chinnaiyan AM, O'Rourke K, Tewari M and Dixit VM (1995) FADD, a novel death domain-containing protein, interacts with the death domain of Fas and initiates apoptosis. Cell 81: 505-512

13. Ting AT, Pimentel-Muinos FX and Seed B (1996) RIP mediates tumor necrosis factor receptor 1 activation of NF-kappaB but not Fas/APO-1-initiated apoptosis. EMBO J. 15: 6189-6196

14. Grimm S, Stanger BZ and Leder P (1996) RIP and FADD: two 'death domain'containing proteins can induce apoptosis by convergent, but dissociable, pathways. Proc. Natl. Acad. Sci. USA 93: 10923-10927

15. Chou JJ, Matsuo H, Duan H and Wagner G (1998) Solution structure of the RAIDD CARD and model for CARD/CARD interaction in caspase-2 and caspase-9 recruitment. Cell 94: 171-180

16. Duan $\mathrm{H}$ and Dixit VM (1997) RAIDD is a new 'death' adaptor molecule. Nature 385: $86-89$

17. Liu Z, Hsu H, Goeddel DV and Karin M (1996) Dissection of TNF receptor 1 effector functions: JNK activation is not linked to apoptosis while NF- $k$ B activation prevents cell death. Cell 87: 565-576
18. Zumbansen M and Stoffel W (1997) Tumor necrosis factor alpha activates NFkappaB in acid sphingomyelinase-deficient mouse embryonic fibroblasts. J. Biol. Chem. 272: 10904-10909

19. Schutze S, Wiegmann K, Machleidt T and Kronke M (1995) TNF-induced activation of NF-kappa B. Immunobiology 193: 193-203

20. Wang CY, Mayo MW, Korneluk RG, Goeddel DV and Baldwin Jr AS. (1998) NFkappaB antiapoptosis: induction of TRAF1 and TRAF2 and c-IAP1 and c-IAP2 to suppress caspase-8 activation. Science 281: 1680-1683

21. Beg AA and Baltimore D (1996) An essential role for NF-kappaB in preventing TNF-alpha-induced cell death. Science 274: 782-784

22. Van Antwerp DJ, Martin SJ, Kafri T, Green DRand Verma IM (1996) Suppression of TNF-alpha-induced apoptosis by NF-kappaB. Science 274: 787-789

23. Barkett M and Gilmore TD (1999) Control of apoptosis by Rel/NF-kappaB transcription factors. Oncogene 18:6910-6924

24. Lin KI, DiDonato JA, Hoffmann A, Hardwick JM and Ratan RR (1998) Suppression of steady-state, but not stimulus-induced NF-kappaB activity inhibits alphavirus-induced apoptosis. J. Cell. Biol. 141: 1479-1487

25. Lin KI, Lee SH, Narayanan R, Baraban JM, Hardwick JM and Ratan RR (1995) Thiol agents and Bcl-2 identify an alphavirus-induced apoptotic pathway that requires activation of the transcription factor NF-kappa B. J Cell Biol 131:1149 1161

26. Wang CY, Cusack JC Jr, Liu R and Baldwin Jr AS. (1999) Control of inducible chemoresistance: enhanced anti-tumor therapy through increased apoptosis by inhibition of NF-kappaB. Nat. Med. 5: 412-417

27. Kimura K, Markowski M, Bowen C and Gelmann EP (2001) Androgen blocks apoptosis of hormone-dependent prostate cancer cells. Cancer Res. 61:56115618

28. Bowen C, VoellerHJ, Kikly Kand Gelmann EP (1999) Synthesis of procaspases3 and -7 during apoptosis in prostate cancer cells. Cell. Death Differ. 6: 394-401

29. Marcelli M, Cunningham GR, Haidacher SJ, Padayatty SJ, Sturgis L, Kagan $C$ and Denner L (1998) Caspase-7 is activated during lovastatin-induced apoptosis of the prostate cancer cell line LNCaP. Cancer Res. 58: 76-83

30. TudelaJ, Garcia-Canovas F, Garcia-Carmona F, Iborra JL and Lozano JA (1986) Irreversible inhibition of trypsin by TLCK. A continuous method for kinetic study of irreversible enzymatic inhibitors in the presence of substrate. Int. J. Biochem. 18 : 285-288

31. Pasternack MS, Sitkovsky MV and Eisen HN (1983) The site of action of N-alphatosyl-L-lysyl-chloromethyl-ketone (TLCK) on cloned cytotoxic T lymphocytes. J. Immunol. 131: 2477-2483

32. Bowen C, Spiegel S and Gelmann EP (1998) Radiation-induced apoptosis mediated by retinoblastoma protein. Cancer Res. 58: 3275-3281

33. Das KC, Lewis-Molock Y and White CW (1995) Thiol modulation of TNF alpha and IL-1 induced MnSOD gene expression and activation of NF-kappa B. Mol. Cell Biochem. 148: 45-57

34. Saldeen J and Welsh N (1994) Interleukin-1 beta induced activation of NF-kappa $\mathrm{B}$ in insulin producing RINm5F cells is prevented by the protease inhibitor $\mathrm{N}$ alpha-p- tosyl-L-lysine chloromethylketone. Biochem. Biophys. Res. Commun. 203: $149-155$

35. Mellits KH, Hay RT and Goodbourn S (1993) Proteolytic degradation of MAD3 (I kappa B alpha) and enhanced processing of the NF-kappa B precursor 105 are obligatory steps in the activation of NF-kappa B. Nucleic Acids Res. 21: 5059 5066

36. Sweeney EA, Inokuchi J and Igarashi Y (1998) Inhibition of sphingolipid induced apoptosis by caspase inhibitors indicates that sphingosine acts in an earlier part of the apoptotic pathway than ceramide. FEBS Lett. 425: 61-65.

37. Levkau B, Scatena M, Giachelli CM, Ross R and Raines EW (1999) Apoptosis overrides survival signals through a caspase-mediated dominant-negative NFkappa B loop. Nat. Cell Biol. 1: 227-233

38. Wang CY, Guttridge DC, Mayo MW and Baldwin Jr AS. (1999) NF-kappaB induces expression of the $\mathrm{Bcl}-2$ homologue $\mathrm{A} 1 / \mathrm{Bfl}-1$ to preferentially suppress chemotherapy-induced apoptosis. Mol. Cell Biol. 19: 5923-5929

39. Sohur US, Chen CL, Hicks DJ, Yull FE and Kerr LD (2000) Nuclear factorkappaB/Rel is apoptogenic in cytokine withdrawal-induced programmed cell death. Cancer Res. 60: 1202-1205

40. Qin ZH, Chen RW, Wang Y, Nakai M, Chuang DM and Chase TN (1999) Nuclear factor kappaB nuclear translocation upregulates c-Myc and p53 expression during NMDA receptor-mediated apoptosis in rat striatum. J. Neurosci. 19: 4023-4033 
41. Qin ZH, Wang Y, Nakai M and Chase TN (1998) Nuclear factor-kappa B contributes to excitotoxin-induced apoptosis in rat striatum. Mol. Pharmacol. 53: $33-42$

42. Ryan KM, Ernst MK, Rice NR and Vousden KH (2000) Role of NF-kappaB in p53 mediated programmed cell death [In Process Citation]. Nature 404: 892-897

43. Foo SY and Nolan GP (1999) NF-kappaB to the rescue: RELs, apoptosis and cellular transformation. Trends Genet. 15:229-235

44. Kuhnel F, Zender L, Paul Y, Tietze MK, Trautwein C, Manns M and Kubicka S (2000) NFkappaB mediates apoptosis through transcriptional activation of Fas (CD95) in adenoviral hepatitis. J. Biol. Chem. 275: 6421-6427

45. Dong Z, Saikumar P, Weinberg JM and Venkatachalam MA (1997) Internucleosomal DNA cleavage triggered by plasma membrane damage during necrotic cell death. Involvement of serine but not cysteine proteases. Am. J. Pathol. 151: 1205-1213

46. Shi L, Kam CM, Powers JC, Aebersold R and Greenberg AH (1992) Purification of three cytotoxic lymphocyte granule serine proteases that induce apoptosis through distinct substrate and target cell interactions. J. Exp. Med. 176: 1521 1529

47. Gong B, Chen Q, Endlich B, Mazumder S and Almasan A (1999) lonizing radiation-induced, Bax-mediated cell death is dependent on activation of cysteine and serine proteases. Cell Growth Differ. 10: 491-502

48. Lotem J and Sachs $L$ (1996) Differential suppression by protease inhibitors and cytokines of apoptosis induced by wild-type p53 and cytotoxic agents. Proc. Natl. Acad. Sci. USA 93: 12507-12512

49. Stefanis L, Troy CM, Qi H and Greene LA (1997) Inhibitors of trypsin-like serine proteases inhibit processing of the caspase Nedd-2 and protect PC12 cells and sympathetic neurons from death evoked by withdrawal of trophic support. J. Neurochem. 69: 1425-1437
50. Shaw E and Springhorn S (1967) Identification of the histidine residue at the active center of trypsin labelled by TLCK. Biochem. Biophys. Res. Commun. 27: $391-397$

51. Heinrich M, Wickel M, Schneider-Brachert W, Sandberg C, Gahr J, Schwandner R, Weber T, Saftig P, Peters C, Brunner J, Kronke M and Schutze S (1999) Cathepsin D targeted by acid sphingomyelinase-derived ceramide [published erratum appears in EMBO J 2000 Jan 17; 19(2): 315]. EMBO J. 18: 5252-5263

52. Huang Y, Sheikh MS, Fornace Jr AJ and Holbrook NJ (1999) Serine protease inhibitor TPCK prevents Taxol-induced cell death and blocks c-Raf-1 and Bcl-2 phosphorylation in human breast carcinoma cells. Oncogene 18: 3431-3439

53. Nava VE, Cuvillier O, Edsall LC, Kimura K, Milstien S, Gelmann EP and SpiegelS (2000) Sphingosine enhances apoptosis of radiation-resistant prostate cancer cells. Cancer Res. 60: 4468-4474

54. Garzotto M, Haimovitz-Friedman A, Liao WC, White-Jones M, Huryk R, Heston WD, Cardon-Cardo C, Kolesnick R and Fuks Z (1999) Reversal of radiation resistance in $\mathrm{LNCaP}$ cells by targeting apoptosis through ceramide synthase. Cancer Res. 59: 5194-5201

55. Lee SJ, Dimtchev A, Lavin MF, Dritschilo A and Jung M (1998) A novel ionizing radiation-induced signaling pathway that activates the transcription factor NFkappaB. Oncogene 17: 1821-1826

56. Kyprianou N, King ED, Bradbury D and Rhee JG (1997) bcl-2 over-expression delays radiation-induced apoptosis without affecting the clonogenic survival of human prostate cancer cells. Int. J. Cancer 70: 341-348 